\title{
Photosynthetic gas exchange and antioxidative system in common bean plants infected by Colletotrichum lindemuthianum and supplied with silicon
}

\author{
Leonora R. Polancoㄹ, Fabrício A. Rodrigues ${ }^{1}$, Kelly J. T. Nascimentoㄹ, Maria F. A. Cruz ${ }^{1}$, Carmen R. S. \\ Curvelo $^{1}$, Fábio M. DaMatta ${ }^{2}$ \& Francisco X. R. Vale ${ }^{1}$ \\ ${ }^{1}$ Departamento de Fitopatologia, ${ }^{2}$ Departamento de Biologia Vegetal, Universidade Federal de Viçosa, 36570-900, Viçosa, \\ MG, Brazil
}

Author for correspondence: Fabrício A. Rodrigues, e-mail: fabricio@ufv.br

\begin{abstract}
This study investigated the effects of silicon ( $\mathrm{Si}$ ) on the resistance of common bean plants to anthracnose caused by Colletotrichum lindemuthianum. The plants were grown in a nutrient solution containing 0 (control) or $2 \mathrm{mM} \mathrm{Si}(+\mathrm{Si})$ and both photosynthesis and antioxidative metabolism levels were evaluated. The Si concentrations in the leaf tissues of +Si plants increased by $33 \%$ in comparison to those of control plants. Anthracnose severity was reduced by $34 \%$ in + Si plants in comparison to control plants. The net carbon assimilation rate, stomatal conductance to water vapor and transpiration rate values were significantly higher in $+\mathrm{Si}$ plants than in control plants. The activities of superoxide dismutase (SOD), ascorbate peroxidase (APX) and glutathione reductase (GR) tended to be higher in + Si plants than in control plants. The hydrogen peroxide concentration was significantly lower in + Si plants than in control plants. In conclusion, the Si supply was associated with lower anthracnose severity and up-regulation of antioxidant enzymes, which in turn might be associated with better gas exchange in +Si plants. The impaired photosynthetic performance in +Si plants was associated with stomatal limitations, whereas in control plants those impairments likely reflected dysfunctions at the level of biochemical reactions involved in $\mathrm{CO}_{2}$ fixation. Key words: Colletotrichum lindemuthianum, antioxidative enzymes, foliar disease, mineral nutrition, photosynthesis.
\end{abstract}

\section{INTRODUCTION}

Among the diseases that affect the common bean (Phaseolus vulgaris L.), anthracnose, caused by the hemibiotrophic fungus Colletotrichum lindemuthianum (Sacc. and Magnus) Scrib, is one of the most destructive (Pastor-Corrales, 1985). Leaves, stems, branches, pods and seeds can be infected by C. lindemuthianum (Hall, 1991). In seedlings, typical symptoms of anthracnose include dark lesions on the cotyledons and hypocotyls; in the leaves of adult plants, the symptoms typically consist of dark brown or brown lesions in the petioles and in the main and secondary veins. The lesions are roundish, depressed, of different sizes and with clear centers, delimited by a slightly protruding black ring and surrounded by a reddish coffeecolored border. When the relative humidity and temperature are favorable, conidia are produced in the centers of these lesions and are dispersed by water to initiate new infection cycles of the pathogen. Full crop failure can occur when infected seeds or susceptible cultivars are used and environmental conditions are favorable for the occurrence of anthracnose epidemics (Hall, 1991).

The most viable option for anthracnose control is the use of resistant cultivars, which can be difficult to achieve because there are several physiological races of C. lindemuthianum (Rava et al., 1994). Spraying with systemic fungicides is another option to reduce the yield losses caused by this disease (Hall, 1991). In light of these concerns, alternative methods for anthracnose control are necessary to reduce the yield losses in beans caused by $C$. lindemuthianum. Silicon ( $\mathrm{Si}$ ), although not considered an essential nutrient for plants, stands out for its potential to decrease the intensities of important diseases in several crops, especially grasses and some dicots such as beans, cucumber and soybeans (Datnoff et al., 2007). For necrotrophic pathogens such as Rhizoctonia solani and Bipolaris oryzae on rice and Bipolaris sorokiniana on wheat, the supply of Si to plants reduced the severity of the diseases caused these pathogens (Rodrigues et al. 2001; Dallagnol et al. 2009; Domiciano et al., 2010). For the pathosystem rice-Pyricularia oryzae, the increased resistance of plants supplied with Si was associated with an increase in the density of long and short silicate cells in the leaf epidermis and a thick silica layer below the cuticle that formed a physical barrier that likely prevented or slowed fungus penetration (Kim et al., 2002). The biochemical and physiological mechanisms potentiated by Si include higher concentration of phenolics, lignin and phytoalexins, an increase in the activities of defense enzymes such as chitinases and $\beta-1,3-$ glucanases and the rapid, strong transcription of genes 
related to host resistance (Datnoff et al., 2007; Brunings et al., 2009). Polanco et al. (2012) reported that higher Si concentrations in the leaf tissues of bean plants supplied with this element were associated with a reduced area under the anthracnose progress curve in association with higher activities of chitinases, phenylalanine ammonia-lyases and lipoxygenases and an increased concentration of lignin. In the $C$. lindemuthianum-bean pathosystem, $\mathrm{Si}$ reduced both the area under the anthracnose incidence progress curve and the area under the anthracnose severity progress curve (Moraes et al., 2006). According to Menzies et al. (1992), phenolics accumulated more rapidly in the epidermal cells of cucumber plants supplied with $\mathrm{Si}$ and colonized by Podosphaera xanthii. Oat plants deprivated of $\mathrm{Si}$ increased the activity of phenylalanine ammonia lyase and, consequently, the accumulation of phenolic compounds in epidermal cells colonized by Blumeria graminis f.sp. avenae (Carver et al., 1998). Furthermore, in the context of Pythium ultimum infection, the activities of chitinases, peroxidases and polyphenoloxidases were much higher on the roots of cucumber plants supplied with Si than on roots of plants that were not supplied with this element (Chérif et al., 1994).

Photosynthesis is a critical process for crop growth and performance, and it can be dramatically impaired when leaves are infected by pathogens (Berger et al., 2007). The decrease in the net carbon assimilation rate of infected leaves has been attributed to decreases in mesophyll and/ or stomatal conductance of $\mathrm{CO}_{2}$, impairments in the rates of biochemical reactions of photosynthesis, changes in the number or structure of chloroplasts or changes in the secretion of phytotoxic chemicals into asymptomatic tissue (Berghaus \& Reisener, 1985; Meyer et al., 2001; Pinkard $\&$ Mohammed, 2006). In the bean- $C$. lindemuthianum pathosystem, changes in the net carbon assimilation rate are exhibited during the necrotrophic phase: the inhibition of the net carbon assimilation rate takes place in the green tissue around the infection site and has been associated with stomatal closure and reduced ribulose-1,5-bisphosphate carboxylase/oxygenase (Rubisco) activity (Meyer et al., 2001).

Abiotic stresses such as drought, heavy metal toxicity and salinity and biotic stresses such as pathogen infection favor the production of reactive oxygen species (ROS) such as hydrogen peroxide $\left(\mathrm{H}_{2} \mathrm{O}_{2}\right)$ and superoxide anion $\left(\mathrm{O}_{2}^{-}\right)$and hydroxyl $\left(\mathrm{OH}^{-}\right)$radicals (Iturbe Ormaetxe et al., 1998). Upon pathogen attack, the generated ROS cause lipid peroxidation in the plasma membrane and increase the concentration of total 2-thiobarbituric acid (TBA)-reactive substances (Resende et al., 2012). To mitigate and repair the cellular damage caused by the ROS, plants have developed protective mechanisms which involve the production of low molecular weight antioxidant molecules such as ascorbate, glutathione, $\alpha$-tocopherol and some carotenoids as well as antioxidant enzymes such as superoxide dismutase, catalase, ascorbate peroxidase and glutathione reductase (Gunes et al., 2007). Superoxide dismutase catalyzes the dismutation of $\mathrm{O}_{2}^{-}$to $\mathrm{H}_{2} \mathrm{O}_{2}$ and oxygen. Because $\mathrm{H}_{2} \mathrm{O}_{2}$ is cytotoxic, it is then detoxified by the catalase to produce oxygen and water (Zhu et al., 2004). In the ascorbate-glutathione cycle, ascorbate peroxidase reduces $\mathrm{H}_{2} \mathrm{O}_{2}$ using the ascorbate molecule as an electron donor (Noctor \& Foyer, 1998). The oxidized ascorbate is then reduced by reduced glutathione, which is produced from oxidized glutathione by glutathione reductase (GR) in a reaction that involves the consumption of NADPH (Lin \& Kao, 2000). The activities of antioxidant enzymes in several crops, such as barley, cucumber, spinach and wheat in the presence of different types of abiotic stress were greatly improved in the presence of $\mathrm{Si}$ (Liang et al., 2003; Gunes et al., 2007; Gong et al., 2008).

To the best of our knowledge, the effects of $\mathrm{Si}$ on enhancing bean resistance against infection by $C$. lindemuthianum at the levels of both photosynthesis and antioxidative metabolism have never been investigated. Therefore, this study aimed to determine whether common bean plants supplied with Si during the course of infection with $C$. lindemuthianum could maintain photosynthesis at desirable physiological levels with a reduced oxidative metabolism.

\section{MATERIAL AND METHODS}

\section{Nutrient solution preparation and plant growth}

The nutrient solution used in this study was prepared according to Liao et al. (2004) and consisted of $3 \mathrm{mM} \mathrm{KNO}_{3}$, $2 \mathrm{mM} \mathrm{Ca}\left(\mathrm{NO}_{3}\right)_{2} \cdot 4 \mathrm{H}_{2} \mathrm{O}, 0.5 \mathrm{mM} \mathrm{MgSO}{ }_{4} \cdot 7 \mathrm{H}_{2} \mathrm{O}, 0.25 \mathrm{mM}$ $\left(\mathrm{NH}_{4}\right)_{2} \mathrm{SO}_{4}, 0.5 \mathrm{mM} \mathrm{NH} \mathrm{H}_{2} \mathrm{PO}_{4}, 12.5 \mathrm{mM} \mathrm{H} \mathrm{BO}_{3}, 1 \mu \mathrm{M}$ $\mathrm{ZnSO}_{4} \cdot 7 \mathrm{H}_{2} \mathrm{O}, 0.25 \mu \mathrm{M} \mathrm{CuSO}_{4} .5 \mathrm{H}_{2} \mathrm{O}, 0.25 \mu \mathrm{M} \mathrm{MnCl} 2.4 \mathrm{H}_{2} \mathrm{O}$, $0.25 \mu \mathrm{M}\left(\mathrm{NH}_{4}\right)_{6} \mathrm{Mo}_{7} \mathrm{O}_{24} \cdot 4 \mathrm{H}_{2} \mathrm{O}, 25 \mu \mathrm{M} \mathrm{FeSO}_{4} \cdot 7 \mathrm{H}_{2} \mathrm{O}$ and $25 \mu \mathrm{M}$ Na-EDTA. The Si, provided as monosilicic acid, was obtained by passing potassium silicate through cationexchange resin (Amberlite IR-120B, $\mathrm{H}^{+}$form; Sigma-Aldrich) (Dallagnol et al., 2009). The Si concentrations used were 0 (control) and $2 \mathrm{mM}(+\mathrm{Si})$. The addition of monosilicic acid to the nutrient solution did not alter the $\mathrm{pH}$. Bean seeds from the cultivar "Pérola", which is susceptible to $C$. lindemuthianum (Polanco et al., 2012) were surface sterilized in a solution of sodium hypochlorite $10 \%$ (vol/vol) and subsequently washed with sterile water for $2 \mathrm{~min}$, transferred to filter paper soaked with sterile water and germinated for five days in a growth chamber (MA-835/2106UR; Marconi) at $25^{\circ} \mathrm{C}$. Seedlings were grown in a hydroponic system containing half-ionic strength nutrient solution, as mentioned above, without the addition of Si for two days to allow for acclimation. Subsequently, the seedlings were transferred to new plastic pots (25-cm-diameter) containing $5 \mathrm{~L}$ of nutrient solution with or without $\mathrm{Si}$ under aeration until the end of the experiments. The nutrient solution was changed every four days or when the electrical conductivity reached $85 \%$ of the initial value. The $\mathrm{pH}$ of the nutrient solution was checked daily and maintained at 5.5 using solutions of $\mathrm{NaOH}$ or $\mathrm{HCl}$ (1 M) when necessary. 


\section{Inoculation procedure}

The isolate 81-538 (race 81) of C. lindemuthianum, obtained from the Bean Fungus Collection Culture from the Dep. de Biologia Geral, Universidade Federal de Viçosa, was used in this study. The isolate was preserved on strips of filter paper placed into glass tubes containing silica gel at $4^{\circ} \mathrm{C}$. Pieces of filter paper with fungal mycelia were transferred to Petri dishes containing potato-dextrose-agar (PDA). Inoculum production was made based on Polanco et al. (2012). The suspension was filtered through double cotton gauze and adjusted to a concentration of $1.2 \times 10^{6}$ conidia $\mathrm{mL}^{-1}$ using a Neubauer-counting chamber. Plants were allowed to grow for 21 days (V5 growth stage, $5^{\text {th }}$ trifoliolate unfolded at node 6 and branching) in a hydroponic culture containing 0 or $2 \mathrm{mM} \mathrm{Si}$ and then inoculated with a conidial suspension of $C$. lindemuthianum applied as a fine mist to the adaxial and abaxial leaves of each plant until runoff using a DeVilbiss atomizer No. 15. One percent gelatin (w/vol) was added to the sterile water used to prepare the conidial suspension to aid conidial adhesion to the leaves. Immediately after inoculation, the plants were transferred to a growth chamber with temperature of $20 \pm 2^{\circ} \mathrm{C}$, relative humidity of $90 \pm 5 \%$ and irradiance of $700 \mu \mathrm{mol}$ photons $\mathrm{m}^{-2} \mathrm{~s}^{-1}$ provided by white fluorescent lamps $(12 \mathrm{~h}$ light $/ 12 \mathrm{~h}$ dark) for $24 \mathrm{~h}$. After this period, the plants were transferred to a plastic mist growth chamber (MGC) as described by Polanco et al. (2012). Non-inoculated plants were kept in a separate MGC, but exposed to the same conditions as the inoculated plants.

\section{Evaluation of anthracnose severity}

Anthracnose severity was evaluated on the fourth trifoliate leaf of each plant at 144 hours after inoculation (hai) using the diagrammatic scale with severity values ranging from 0.1 to $24 \%$ (Godoy et al., 1997).

\section{Determination of leaf gas exchange parameters}

Leaf gas exchange parameters were determined using a portable open-flow gas exchange system (LI-6400; LICOR) equipped with a blue/red light source (LI-6400-02B). The net $\mathrm{CO}_{2}$ assimilation rate $(A)$, stomatal conductance to water vapor $\left(g_{\mathrm{s}}\right)$, internal $\mathrm{CO}_{2}$ concentration $\left(C_{\mathrm{i}}\right)$ and transpiration rate $(E)$ were measured on the fourth trifoliate leaf from 08:00 to 11:00 hours (solar time), which is when $A$ was at its maximum, under artificial PAR $(1,000 \mu \mathrm{mol}$ photons $\left.\mathrm{m}^{-2} \mathrm{~s}^{-1}\right)$ at the leaf level and $390 \mu \mathrm{mol} \mathrm{CO}_{2} \mathrm{~mol}^{-1}$ air. All measurements were performed at ambient temperature $\left(27 \pm 0.9^{\circ} \mathrm{C}\right)$ at $0,36,48,72$ and 120 hai.

\section{Biochemical assays}

Samples from the third and fourth trifoliate leaves of each plant were collected at 24, 48, 72, 120 and 144 hai. Leaf samples collected from non-inoculated plants served as the controls ( 0 dai). The leaf samples were kept in liquid nitrogen during the sampling and then stored at $-80^{\circ} \mathrm{C}$ until required.
For the determination of the activities of superoxide dismutase (SOD, EC 1.15.1.1), ascorbate peroxidase (APX, EC 1.11.1.11), catalase (CAT, EC 1.11.1.6) and glutathione reductase (GR, EC 1.8.1.7), $0.3 \mathrm{~g}$ of leaf tissue was ground into a fine powder in a mortar and pestle with liquid nitrogen. The fine powder was homogenized in an ice bath with 60 $\mathrm{mg}$ polyvinylpolypyrrolidone and the following additional reagents: for SOD, $1 \mathrm{~mL} 100 \mathrm{mM}$ potassium phosphate buffer ( $\mathrm{pH} 7.8$ ), $0.1 \mathrm{mM}$ EDTA and $0.1 \% \mathrm{v} / \mathrm{v}$ Triton X-100; for CAT, $1 \mathrm{~mL} 100 \mathrm{mM}$ potassium phosphate buffer $(\mathrm{pH}$ 7.0) and $0.1 \mathrm{mM}$ EDTA; for APX, $1 \mathrm{~mL} 50 \mathrm{mM}$ potassium phosphate buffer ( $\mathrm{pH} 7.0)$ and $1 \mathrm{mM}$ ascorbate; and for GR, $1 \mathrm{~mL} 100 \mathrm{mM}$ Tris-HCl (pH 7.5), $50 \mathrm{mM}$ EDTA, 10 $\mathrm{mM}$ isoascorbate, $9 \mathrm{mM}$ 2-mercaptoethanol and $0.1 \%(\mathrm{v} / \mathrm{v})$ Triton X-100 (Resende et al., 2012). The homogenates were centrifuged at $15,000 \mathrm{~g}$ for $15 \mathrm{~min}$ at $4^{\circ} \mathrm{C}$ and the supernatants were used as crude enzyme extracts. The SOD activity was assayed by the method of Giannopolitis \& Ries (1977) by measuring its ability to inhibit the photochemical reduction of $p$-nitrotetrazolium blue (NTB) to formazan by converting $\mathrm{O}_{2}^{-}$in $\mathrm{H}_{2} \mathrm{O}_{2}$. The reaction was initiated after the addition of $5 \mu \mathrm{L}$ of the crude enzyme extract to 3 $\mathrm{mL}$ of a mixture containing $50 \mathrm{mM}$ potassium phosphate buffer (pH 7.8), $14 \mathrm{mM}$ methionine, $75 \mu \mathrm{M}$ NTB, $0.1 \mu \mathrm{M}$ EDTA and $2 \mu \mathrm{M}$ riboflavin. The production of formazan blue, resulting from the photoreduction of NTB, was monitored by measuring the increase in absorbance at 560 nm (Giannopolitis \& Ries, 1977). One unit of SOD was defined as the amount of enzyme necessary to inhibit NTB photoreduction by $50 \%$ and was interpreted as the total superoxide scavenging capacity. For APX, the reaction was started by adding $20 \mu \mathrm{L}$ of the crude enzyme extract to 3 $\mathrm{mL}$ of a mixture containing $50 \mathrm{mM}$ potassium phosphate buffer ( $\mathrm{pH} 7.0), 0.5 \mathrm{mM}$ ascorbate and $0.1 \mathrm{mM} \mathrm{H}_{2} \mathrm{O}_{2}$. The APX activity was determined by the rate of ascorbate oxidation at $290 \mathrm{~nm}$ (Nakano \& Asada, 1981). The CAT activity was estimated by the rate of $\mathrm{H}_{2} \mathrm{O}_{2}$ decomposition at $240 \mathrm{~nm}$ (Havir \& McHale, 1989). The reaction was initiated by adding $20 \mu \mathrm{L}$ of the crude enzyme extract to $3 \mathrm{~mL}$ of a mixture containing $50 \mathrm{mM}$ potassium phosphate buffer $(\mathrm{pH}$ 7.8) and $12.5 \mathrm{mM} \mathrm{H}_{2} \mathrm{O}_{2}$. The GR activity was determined by the rate of NADPH oxidation at $340 \mathrm{~nm}$. The reaction was initiated by adding $20 \mu \mathrm{L}$ of the crude enzyme extract to a mixture containing $50 \mathrm{mM}$ Tris- $\mathrm{HCl}$ ( $\mathrm{pH} 7.5), 10 \mathrm{mM}$ reduced glutathione, $3 \mathrm{mM} \mathrm{MgCl}$ and $0.15 \mathrm{mM}$ NADPH. The decrease in absorbance was determined at $340 \mathrm{~nm}$ for $1 \mathrm{~min}$ at $30^{\circ} \mathrm{C}$. An extinction coefficient of $6.22 \mathrm{mM}^{-1} \mathrm{~cm}^{-1}$ (Foyer \& Halliwell, 1976) was used to calculate the GR activity. For each enzyme, extractions were performed using leaf samples from the three plants of each replication of the treatments. Each reaction was performed three times using samples from the same extraction. The soluble protein contents of the extracts were measured using the method of Bradford (1976).

For hydrogen peroxide $\left(\mathrm{H}_{2} \mathrm{O}_{2}\right)$ assay, a total of 0.2 $\mathrm{g}$ of frozen leaf tissue was ground into a fine powder using 
a pestle and mortar with liquid nitrogen. The fine powder was homogenized in an ice bath in $2 \mathrm{~mL} 50 \mathrm{mM}$ potassium phosphate buffer ( $\mathrm{pH}$ 6.5) containing $1 \mathrm{mM}$ hydroxylamine. The homogenate was centrifuged at $10,000 \mathrm{~g}$ for $15 \mathrm{~min}$ at $4^{\circ} \mathrm{C}$ (Meyer et al., 2001). The supernatant was used to determine the $\mathrm{H}_{2} \mathrm{O}_{2}$ concentration. The reaction was started by the addition of $50 \mu \mathrm{l}$ of the supernatant to a mixture containing $25 \mathrm{mM}$ sulfuric acid, $100 \mu \mathrm{M}$ ammonium ferrous sulphate, $250 \mu \mathrm{M}$ xylenolorange and $100 \mathrm{mM}$ sorbitol in a volume of $2 \mathrm{~mL}$ (Gay \& Gebicki, 2000). The samples were kept in the dark for $30 \mathrm{~min}$ and the absorbance was recorded at $560 \mathrm{~nm}$. Control samples (blank) for the color of the reagents as well as for the sample extracts were prepared concurrently with the tested samples and subtracted from the absorbance value obtained for each sample. The $\mathrm{H}_{2} \mathrm{O}_{2}$ concentration was expressed as nmol g-1 of fresh matter (FM) with hydrogen peroxide (Sigma-Aldrich) as a standard.

\section{Determination of Si concentration in leaf tissue}

After the end of the experiments, trifoliate leaves from the plants of each replication per treatment were collected, washed with deionized water and dried at $65^{\circ} \mathrm{C}$ for $72 \mathrm{~h}$. Next, the leaves were ground in a Thomas-Wiley mill with a 40-mesh sieve. The concentration of $\mathrm{Si}$ was determined by colorimetric analysis of the alkaline digestion of $0.1 \mathrm{~g}$ of dry leaf tissue (Resende et al., 2012).

\section{Experimental design and statistical analysis}

Two independent experiments were carried out in a completely randomized design with two treatments $(0$ and $2 \mathrm{mM} \mathrm{Si}$ ) and six replications to evaluate the anthracnose severity, the Si concentration in the leaf tissue and the leaf gas exchange parameters. Each replication consisted of a plastic pot containing 5 liters of nutrient solution and three bean plants. A total of 180 plants were used in each experiment (18 plants per each treatment at each evaluation time). The anthracnose severity, leaf $\mathrm{Si}$ concentration and gas exchange parameter data from the two experiments were combined after the determination of the homogeneity of variance by Cochran's test (Gomez \& Gomez, 1994). A third experiment, repeated once, was performed to obtain leaves for the biochemical assays. The $\mathrm{H}_{2} \mathrm{O}_{2}$ concentration and enzyme activity data were submitted to analysis of variance, and the treatment means were compared by $t$-test $(P \leq 0.05)$ using SAS software (SAS Institute). The correlations among the $\mathrm{Si}$ concentration in the leaf tissue, severity of anthracnose and the leaf gas exchange parameters $A, g_{\mathrm{s}}, E$ and $C_{\mathrm{i}}$ were evaluated based on data pooled from two experiments.

\section{RESULTS}

\section{Foliar Si concentration and anthracnose severity}

The Si concentration in the leaf tissues of + Si plants increased by $33 \%$ in comparison to the control plants (Table 1). The anthracnose severity was reduced by $34 \%$ in the $+\mathrm{Si}$ plants relative to the control plants (Table 1).
TABLE 1 - Silicon (Si) concentration and anthracnose severity (Sev) in the leaves of bean plants grown in hydroponic culture containing 0 (control) or $2 \mathrm{mM}(+\mathrm{Si})$ silicon and inoculated with Colletotrichum lindemuthianum.

\begin{tabular}{lcc}
\hline \hline Treatments & Si $\left(\mathbf{d a g ~ k g}^{-1}\right)$ & Sev $(\%)$ \\
\hline Control & 0.84 & 6.30 \\
+Si & 1.25 & 4.16 \\
Student's t-test & $1.22^{*}$ & $3.34^{*}$ \\
\hline CV (\%) & 16.58 & 14.72 \\
\hline
\end{tabular}

${ }^{*}$ Significant at $5 \%$ probability.

$\mathrm{CV}$, Coefficient of variation.

Data are from two pooled experiments $(n=36)$.

\section{Leaf gas exchange parameters}

Silicon supplementation was able to limit the impairment of photosynthetic gas exchange upon infection by $C$. lindemuthianum as indicated by the significantly higher values of $A$ in + Si plants from 36 to 120 hai (Figure 1A), of $g_{\mathrm{s}}$ from 48 to 120 hai (Figure 1B) and of $E$ from 36 to 120 hai (Figure 1C). Infection with $C$. lindemuthianum led to devastating effects on $A$. In control plants, leaves with $6.30 \%$ severity displayed reductions of as much as $80 \%$ in $A$, whereas in the +Si plants, leaf severity was $4.16 \%$ and was accompanied by decreases in $A$ of approximately $40 \%$ as severe as those in control plants at 120 hai (Table 1, Figure 1A).

\section{$\mathrm{H}_{2} \mathrm{O}_{2}$ concentration and enzyme activities}

Overall, the enzyme activities tended to be higher in $+\mathrm{Si}$ plants than in the control plants during the course of infection by $C$. lindemuthianum. For $+\mathrm{Si}$ plants in comparison to the $-\mathrm{Si}$ plants, SOD activity was significantly higher from 48 to 144 hai, APX activity at 0, 36, 48, 120 and 144 hai (Figure 2B), CAT activity at 0 hai (Figure 2C) and GR activity at 36, 48, 72 and 144 hai (Figure 2D). The CAT activity was significantly higher from 36 to 144 hai for -Si plants in comparison to the $+\mathrm{Si}$ plants (Figure 2C). The concentration of $\mathrm{H}_{2} \mathrm{O}_{2}$ was significantly lower in $+\mathrm{Si}$ plants than in control plants from 36 to 144 hai (Figure 3). Similar enzyme activities and $\mathrm{H}_{2} \mathrm{O}_{2}$ concentration results were observed in a pilot experiment (data not shown).

\section{Pearson correlation}

Anthracnose severity was negatively correlated with leaf $\mathrm{Si}$ concentration $(\mathrm{r}=-0.80)$. The $\mathrm{Si}$ concentration was positively correlated with $A, E$ and $g_{\mathrm{s}}(\mathrm{r}=0.89,0.79$ and 0.64 , respectively). Anthracnose severity also correlated negatively with $A, E$ and $g_{\mathrm{s}}(\mathrm{r}=-0.92,-0.96$ and -0.89 , respectively). In addition, $A$ was correlated positively with $E$ and $g_{\mathrm{s}}(\mathrm{r}=0.93$ and 0.87 , respectively). $E$ was positively correlated with $g_{\mathrm{s}}(\mathrm{r}=$ 0.88 ). All of these correlations were significant at $P \leq 0.01$.

\section{DISCUSSION}

In support of previous findings that Si can improve the resistance of several dicots against foliar pathogens 

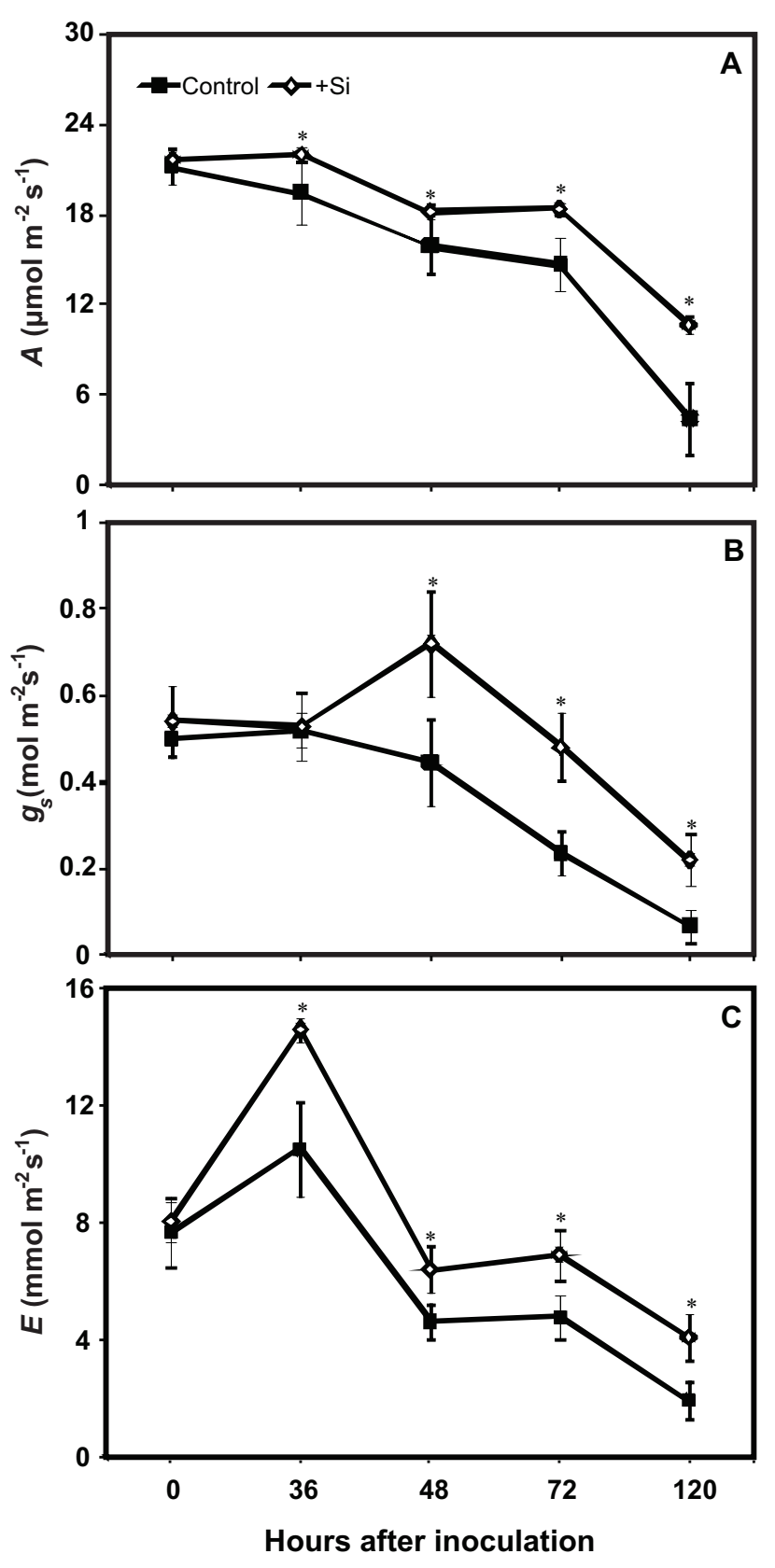

FIGURE 1 - A. Net carbon assimilation rate $(A)$, B. Stomatal conductance to water vapor $\left(g_{s}\right)$, and $\mathbf{C}$. Transpiration rate $(E)$, determined in leaves of bean plants grown in hydroponic culture containing 0 (control) or $2 \mathrm{mM}(+\mathrm{Si})$ silicon and inoculated with Colletotrichum lindemuthianum. The means for the control and $+\mathrm{Si}$ treatments that are followed by asterisks $(*)$ for each evaluation time are significantly different as determined by Student's t-test $(P \leq 0.05)$. The error bars represent the standard deviation of the means of two pooled experiments $(n=36)$.

(Datnoff et al., 2007; Rodrigues et al., 2009), the present study describes the first physiological and biochemical features associated with the increase in the resistance of bean plants supplied with $\mathrm{Si}$ against $C$. lindemuthianum infection. The leaf $\mathrm{Si}$ concentration of $+\mathrm{Si}$ plants (values ranging from 0.9 to up to $1.2 \mathrm{dag} \mathrm{kg}^{-1}$ ) is consistent with what has been reported previously for dicots, which are able to accumulate, on average, 1 dag Si kg-1 (Datnoff et al., 2007). The high Si concentration in bean leaves contributed to decreased anthracnose severity even though they were lower than those in rice, which is a known $\mathrm{Si}$ accumulator that exhibits Si concentrations of up to $5 \mathrm{dag} \mathrm{kg}^{-1}$ of dry mass of shoot (Datnoff et al., 2007; Dallagnol et al., 2009).

It is well known that foliar diseases can dramatically decrease photosynthesis in several crops (Chou et al., 2000; Scholes \& Rolfe, 1996; Berger et al., 2007; Dallagnol et al., 2013; Resende et al., 2012). In the present study, infection by $C$. lindemuthianum on bean leaves caused devastating effects on photosynthetic gas exchange. The effects observed were more dramatic than those previously reported by Bassanezi et al. (2001), who found that $A$ was reduced by more than $50 \%$ in bean leaves with $10 \%$ of anthracnose severity and was reduced by almost $100 \%$ when the severity was above $20 \%$. In the bean- $C$. lindemuthianum interaction, the production of lytic enzymes and non-specific toxins and their diffusion into the leaf tissues, particularly the veins, which are not yet colonized by the fungus, is likely to contribute greatly to the impairment of $A$. Nevertheless, these negative impacts were alleviated to some extent by $\mathrm{Si}$ supplementation. It is possible that $\mathrm{Si}$ acts to potentiate mechanisms of resistance that could reduce the leaf tissue damage caused by $C$. lindemuthianum and ultimately contribute to preventing any abrupt decrease in $A$.

Overall, the decreases in $A$ during the course of C. lindemuthianum infection took place in parallel with decreases in $g_{s}$. The observed decreases in $A$, particularly at 120 hai, are caused by non-stomatal factors, possibly associated with dysfunctions at the level of the biochemical reactions involved in $\mathrm{CO}_{2}$ fixation. These data suggest that stomatal limitations likely play a prominent role in constraining $A$ upon infection by $C$. lindemuthianum in $+\mathrm{Si}$ plants. It is known that $C$. lindemuthianum causes stomatal closure in the green areas of bean leaves that are apparently healthy, reducing $A$ of the entire leaf even under lower disease severity (Meyer et al., 2001). This may be the result of the vein necrosis that often occurs as anthracnose progresses, which abrogates the transport of water and solutes, leading to stomatal closure and, ultimately, imposing dramatic limits on $\mathrm{CO}_{2}$ fixation, as observed in the control plants at advanced stages of fungal infection.

The lower concentration of $\mathrm{H}_{2} \mathrm{O}_{2}$ in the leaves of $+\mathrm{Si}$ inoculated plants support the hypothesis that $\mathrm{Si}$ provides a beneficial effect to plants that undergo major oxidative damage due to pathogen infection, as is the case of $C$. lindemuthianum. Indeed, $\mathrm{Si}$ has been shown to improve the ROS-scavenging antioxidant system in several plant species in response to both abiotic and biotic stresses (Datnoff et al., 2007; Gunes et al., 2007; Gong et al., 2008; Resende et al., 2012). Overall, these data showed that the activities of SOD, APX and GR were higher in the leaves of plants supplied with $\mathrm{Si}$, which could contribute to limit 

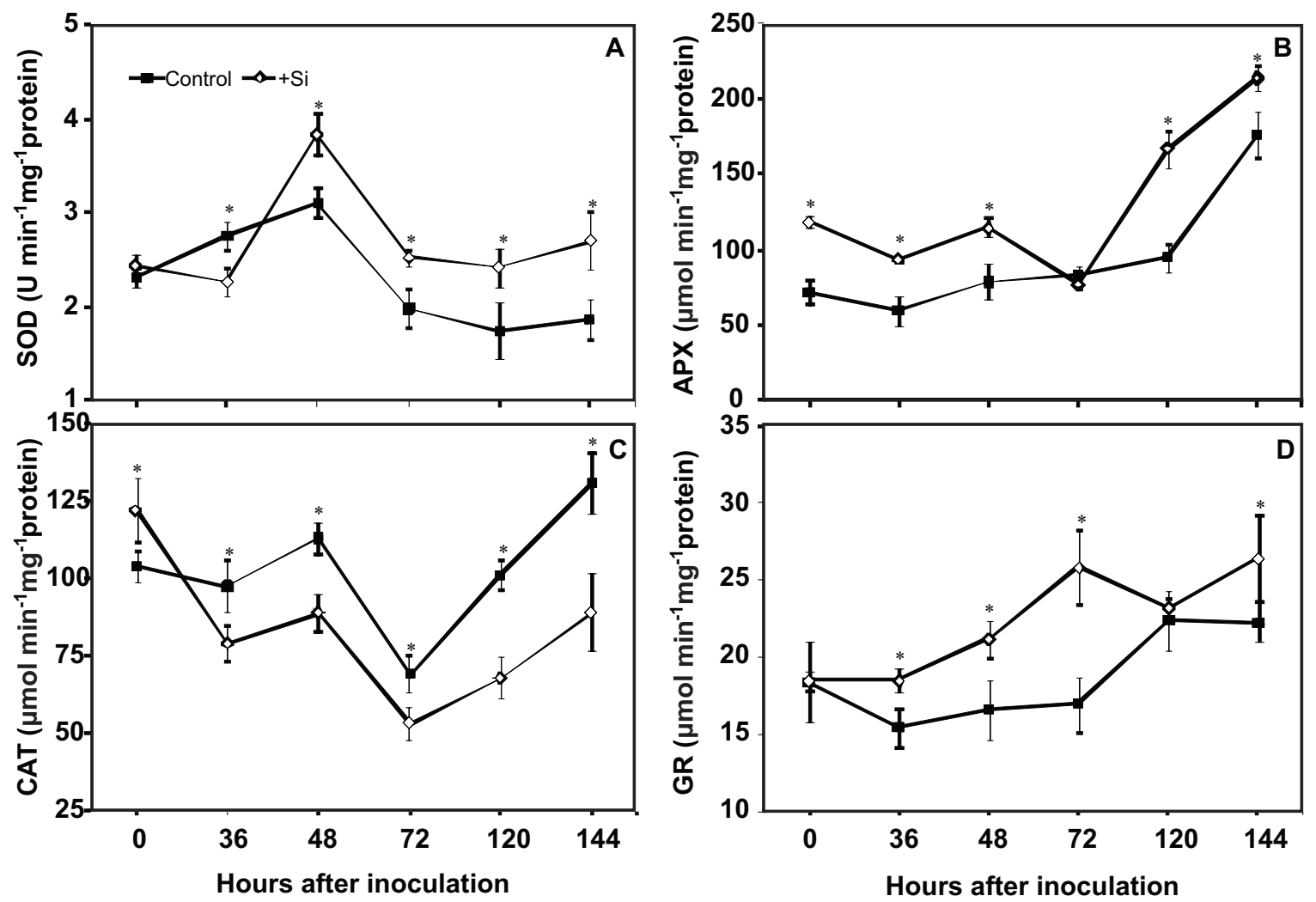

FIGURE 2 - Activities of A. Superoxide dismutase (SOD), B. Ascorbate peroxidase (APX), C. Catalase (CAT), and D. Glutathione reductase (GR), in leaves of bean plants grown in hydroponic culture containing 0 (control) or $2 \mathrm{mM}(+\mathrm{Si}$ ) silicon after the inoculation with Colletotrichum lindemuthianum. The means for the control and + Si treatments that are followed by asterisks $(*)$ for each evaluation time are significantly different as determined by Student's t-test $(P \leq 0.05)$. The error bars represent the standard deviation of the mean $(n=18)$.

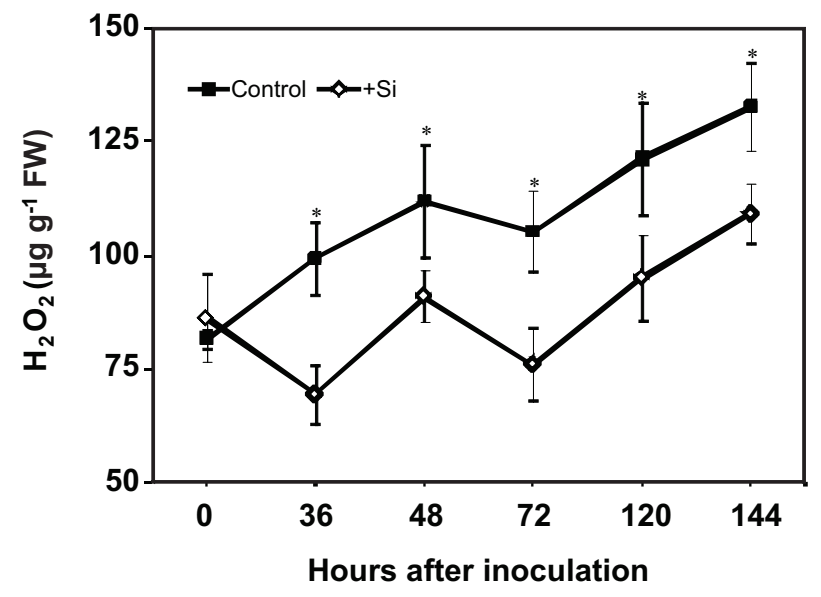

FIGURE 3 - Concentration of hydrogen peroxide $\left(\mathrm{H}_{2} \mathrm{O}_{2}\right)$ in leaves of bean plants grown in hydroponic culture containing 0 (control) or $2 \mathrm{mM}(+\mathrm{Si})$ silicon after the inoculation with Colletotrichum lindemuthianum. The means for the control and + Si treatments that are followed by asterisks $(*)$ for each evaluation time are significantly different as determined by Student's t-test $(P \leq 0.05)$. The error bars represent the standard deviation of the means of two pooled experiments $(n=18)$. FW $=$ fresh weight. the tissue damage caused by $C$. lindemuthianum infection. Intriguingly, CAT activity during the infection of bean leaves by $C$. lindemuthianum was down-regulated by $\mathrm{Si}$ supplementation and no explanation for this response is immediately evident. The affinity of CAT for $\mathrm{H}_{2} \mathrm{O}_{2}$ is lower than that of APX (Smirnoff, 1995). Consequently, the greater APX activity coupled with greater GR activity could compensate for the lower CAT activity in +Si plants. In summary, it is proposed that the high activities of SOD, APX and GR in the leaves of + Si plants may have translated into an effective removal of $\mathrm{H}_{2} \mathrm{O}_{2}$ from the infected leaf tissues. Indeed, defects in gas-exchange performance upon fungal infection can be ameliorated in the presence of Si.

In conclusion, it was demonstrated that the $\mathrm{Si}$ supply to the bean plants was associated with lower disease severity in parallel with the up-regulation of key enzymes in the antioxidant system, which in turn might be associated with improved gas exchange performance. It was also demonstrated that the impaired photosynthetic performance in $+\mathrm{Si}$ plants was largely associated with stomatal limitations, whereas in the control plants, those impairments likely reflected dysfunctions at the level of the biochemical reactions involved in $\mathrm{CO}_{2}$ fixation. Based 
Photosynthetic gas exchange and antioxidative system in common bean plants infected...

on the above observations, it is tempting to speculate that Si can generate a signal that can help bean plants to cope with the deleterious effects of ROS on the cells infected with $C$. lindemuthianum. The confirmation and further identification of the exact nature of this signal, as well as the determination of the precise biological function of $\mathrm{Si}$ nutrition per se, remain important issues and merit future study.

\section{ACKNOWLEDGEMENTS}

FA Rodrigues, FM DaMatta and FXR Vale thank Conselho Nacional de Desenvolvimento Científico e Tecnológico-CNPq for their fellowships. Leonora R Polanco was supported by the PEC-PG program from Coordenação de Aperfeiçoamento de Pessoal de Nível Superior - CAPES. The authors would like to express their appreciation to Prof. Gaspar H Korndörfer for silicon analysis, Prof. Everaldo $\mathrm{G}$ Barros for providing the isolate of $C$. lindemuthianum and Dr. Trazilbo JP Júnior, Mr. Pablo Schulman and Mr. Fernando W Neves for technical assistance. This study was financed by a Fundação de Amparo à Pesquisa do Estado de Minas Gerais - FAPEMIG grant (APQ-01169-09).

\section{REFERENCES}

Bassanezi RB, Amorin L, Bergamin-Filho A, Hau B, Berger RD (2001) Accounting for photosynthetic efficiency of bean leaves with rust, angular leaf spot and anthracnose to assess crop damage. Plant Pathology 50:1-11.

Berger S, Sinha AK, Roitsch T (2007) Plant physiology meets phytopathology: Plant primary metabolism and plant-pathogen interactions. Journal of Experimental Botany 58:4019-4026.

Berghaus R, Reisener HJ (1985) Changes in photosynthesis of wheat plants infected with wheat stem rust (Puccinia graminis f.sp. tritici ). Journal of Phytopathology 112:165-172.

Bradford MN (1976) A rapid and sensitive method for the quantitation of microgram quantities of protein utilizing the principle of protein-dye binding. Analytical Biochemistry 72:248254.

Brunings AM, Datnoff LE, Ma JF, Mitani N, Nagamura Y, Rathinasabapathi B, Kirst K (2009) Differential gene expression of rice in responses to silicon and the rice blast fungus Magnaporthe oryzae. Annals of Applied Biology 155:161-170.

Carver TLW, Robbins MP, Thomas BJ, Troth K, Raistrick N, Zeyen RJ (1998) Silicon deprivation enhances local autofluorescent responses and phenylalanine ammonia lyase activity in oat attacked by Blumeria graminis. Physiological and Molecular Plant Pathology 52:245-257.

Chérif M, Asselin A, Bélanger RR (1994) Defense responses induced by soluble silicon in cucumber roots infected by Pythium spp. Phytopathology 84:236-242.

Chou H, Bundock N, Rolfe SA, Scholes JD (2000) Infection of Arabidopsis thaliana leaves with Albugo candida (white blister rust) causes a reprogramming of host metabolism. Molecular Plant Pathology 1:99-113.
Dallagnol LJ, Rodrigues FA, Mielli MVB, Ma JF, Datnoff LE (2009) Defective active silicon uptake affects some components of rice resistance to brown spot. Phytopathology 99:116-121.

Dallagnol LJ, Rodrigues FA, Chaves ARM, Vale FXR, DaMatta FM (2013) Photosynthesis and sugar concentration are impaired by the defective active silicon uptake in rice plants infected with Bipolaris oryzae. Plant Pathology 62:120-129.

Datnoff LE, Rodrigues FA, Seebold KW (2007) Silicon and plant disease. In: Datnoff LE, Elmer WH, Huber DM (Eds.) Mineral Nutrition and Plant Disease. St Paul MN, USA. APS Press. pp. 233-246.

Domiciano GP, Rodrigues FA, Vale FXR, Xavier Filha MS, Moreira WR, Andrade CCL, Pereira SC (2010) Wheat resistance to spot blotch potentiated by silicon. Journal of Phytopathology 158:334-343.

Foyer CH, Halliwell B (1976) The presence of glutathione and glutathione reductase in chloroplasts: A proposed role in ascorbic acid metabolism. Planta 133:21-25.

Gay C, Gebicki JMA (2000) A critical evaluation of the effect of sorbitol on the ferricxylenol orange hydroperoxide assay. Analytical Biochemistry 284:217-220.

Giannopolitis CN, Ries SK (1977) Superoxide dismutases. I. Occurrence in higher plants. Plant Physiology 59:309-314.

Godoy CV, Carneiro SM, Lamauti MT, Dalla Pria M, Amorim L, Berger RD, Bergamin Filho A (1997) Diagrammatic scales for bean diseases: Development and validation. Zeitschrift für Pflanzenkrankheiten und Pflanzenschutz 104:336-345.

Gomez KA, Gomez AA (1994) Statistical Procedures for Agricultural Research. $2^{\text {nd }}$ Ed. New York NY, USA. Wiley.

Gong HJ, Chen KM, Zhao ZG, Chen GC, Zhou WJ (2008) Effects of silicon on defense of wheat against oxidative stress under drought at different developmental stages. Biologia Plantarum 52:592-596.

Gunes A, Inal A, Bagci EG, Coban S (2007) Silicon-mediated changes on some physiological and enzymatic parameters symptomatic of oxidative stress in barley grown in sodic-B toxic soil. Journal of Plant Physiology 164:807-811.

Hall R (1991) Compendium of Bean Diseases. St Paul MN, USA. APS Press.

Havir EA, McHale NA (1989) Enhanced-peroxidatic activity in specific catalase isozymes of tobacco, barley, and maize. Plant Physiology 91:812-815.

Iturbe-Ormaetxe I, Escudero PR, Arrese-Igor C, Becana M (1998) Oxidative damage in pea plants exposed to water deficit or paraquat. Plant Physiology 116:173-181.

Kim SG, Kim KW, Park EW, Choid D (2002) Silicon-induced cell wall fortification of rice leaves: a possible cellular mechanism of enhanced host resistance to blast. Phytopathology 92:1095-1103.

Liao H, Yan X, Rubio G, Beebe SE, Blair MW, Lynch JP (2004) Genetic mapping of basal root acquisition efficiency in common bean. Functional Plant Biology 31:959-970.

Liang YC, Chen Q, Liu Q, Zhang WH, Ding RX (2003) Exogenous silicon ( $\mathrm{Si}$ ) increases antioxidant enzyme activity and reduces lipid peroxidation in roots of salt-stressed barley (Hordeum vulgare L.). Journal of Plant Physiology 160:11571164. 
Lin CC, $\mathrm{Kao} \mathrm{CH}$ (2000) Effect of $\mathrm{NaCl}$ stress on $\mathrm{H}_{2} \mathrm{O}_{2}$ metabolism in rice leaves. Plant Growth Regulation 30:151-155.

Meyer S, Saccardy K, Rizza F, Genty B (2001) Inhibition of photosynthesis by Colletotrichum lindemuthianum in bean leaves determined by chlorophyll fluorescence imaging. Plant Cell and Environment 24:947-955.

Menzies J, Bowen P, Ehret DL, Glass ADM (1992) Foliar application of potassium silicate reduce severity of powdery on cucumber, muskmelon, and zucchini squash. Journal of the American Society for Horticultural Science 117:902-905.

Moraes SR, Pozza EA, Alves E, Pozza AA, Carvalho JC, Lima $\mathrm{PH}$, Botelho AO (2006) Efeito de fontes de silício na incidência e na severidade da antracnose do feijoeiro. Fitopatologia Brasileira 31:283-291.

Nakano Y, Asada K (1981) Hydrogen peroxide is scavenged by ascorbate-specific peroxidase in spinach chloroplasts. Plant Cell Physiology 22:867-880.

Noctor G, Foyer H (1998) Ascorbate and glutathione: Keeping active oxygen under control. Annual Review of Plant Physiology and Plant Molecular Biology 49:249-279.

Pinkard EA, Mohammed CL (2006) Photosynthesis of Eucalyptus globulus with Mycosphaerella leaf disease. New Phytologist 170:119-127.

Polanco LR, Rodrigues FA, Nascimento KJT, Shulman P, Silva LC, Neves FW, Vale FXR (2012) Biochemical aspects of bean resistance to anthracnose mediated by silicon. Annals of Applied Biology 161:140-150.
Rava CA, Purchio AF, Sartorato A (1994) Caracterização de patótipos de Colletotrichum lindemuthianum que ocorrem em algumas regiões produtoras de feijoeiro comum. Fitopatologia Brasileira 19:167-172.

Resende RS, Rodrigues FA, Cavatte PC, Martins SCV, Moreira WR, Chaves GRM, DaMatta FM (2012) Leaf gas exchange and oxidative stress in sorghum plants supplied with silicon and infected by Colletotrichum sublineolum. Phytopathology 102:892898.

Rodrigues FA, Duarte HSS, Domiciano GP, Souza CA, Korndörfer GH (2009) Foliar application of potassium silicate reduces the intensity of soybean rust. Australasian Plant Pathology 38:366372.

Rodrigues FA, Datnoff LE, Korndörfer GH, Seebold KW, Rush MC (2001) Effect of silicon and host resistance on sheath blight development in rice. Plant Disease 85:827-832.

Scholes J, Rolfe SA (1996) Photosynthesis in localized regions of oat leaves infected with crown rust (Puccinia coronata): Quantitative imaging of chlorophyll fluorescence. Planta 199:573582.

Smirnoff N (1995) Antioxidant systems and plant response to the environment. In: Smirnoff N (Ed.) Environment and Plant Metabolism: Flexibility and Acclimation. Oxford UK. BIOS Scientific Publishers. pp. 217-243.

Zhu Z, Wei G, Li J, Qian Q, Yu J (2004) Silicon alleviates salt stress and increases antioxidant enzymes activity in leaves of salt-stressed cucumber (Cucumis sativus L.). Plant Science 167:527-33.

TPP-2013-0119

Submitted: 9 July 2013

Revisions requested: 1 September 2013

Accepted: 10 October 2013

Section Editor: Marciel J. Stadnik 